Руднев Евгений Евгеньевич

магистрант

Российской академии народного хозяйства

и государственной службы при Президенте РФ

\section{УГРОЗЫ ВНЕШНЕЭКОНОМИЧЕСКОЙ БЕЗОПАСНОСТИ РФ ПРИ ВЗАИМОДЕЙСТВИИ С НЕПРИЗНАННЫМИ ГОСУДАРСТВАМИ НА ПОСТСОВЕТСКОМ ПРОСТРАНСТВЕ}

Аннотация:

Актуальность темы исследования обусловлена тем, что внешнеэкономическое сотрудничество с непризнанными республиками является неотъемлемой частью экономики России в условиях современной действительности. Автором определена система экономических отношений Российской Федерации с непризнанными государствами, проанализирована степень финансового содействия России этим территориям и идентифицированы угрозы внешнеэкономической безопасности для страны при осуществлении этой деятельности. Представлен обзор альтернативных вариантов дальнейшего взаимодействия в сфере внешнеэкономической деятельности Российской Федерации с непризнанными государствами на постсоветском пространстве в целях обеспечения внешнеэкономической безопасности государства. Автор приходит к выводу, что отношения с непризнанными государствами играют важную роль в реализации национальных интересов Российской Федерации на международной арене, финансовая поддержка оказывается достаточно в прагматичных иелях, определенных нашим госу дарством. Изложен наиболее приемлемый для Российской Федерации путь нивелирования угроз экономической безопасности, надежного и законного способа обхода санкций. В заключение утверждается, что осуществление внешнеэкономической деятельности с непризнанными государствами позволяет России использовать те стратегии урегулирования «замороженных конфликтов», которые являются эффективными для топливноэнергетического давления на западный мир и обеспечения военного спокойствия на государственных границах.

Ключевые слова:

внешнеэкономическая безопасность, внешнеэкономическая деятельность, внешнеэкономические угрозы, непризнанные государства, постсоветское пространство, финансовая поддержка, экономические санкции, сырьевой экспорт, cmpameгия, национальные интересы.
Rudnev Yevgeny Yevgenyevich

Master's Degree student, Russian Presidential Academy of the National Economy and Public Administration

\section{THREATS TO RUSSIA'S FOREIGN ECONOMIC SECURITY WHEN INTERACTING WITH UNRECOGNIZED STATES IN THE POST-SOVIET SPACE}

Summary:

The relevance of the research is determined by the fact that foreign economic cooperation with unrecognized states is an integral part of the Russian economy in the modern world. The author defines the system of economic relations of the Russian Federation with unrecognized states, analyzes the degree of Russia's financial assistance to them and identifies threats to foreign economic security while implementing this foreign economic activity. The paper provides an overview of alternatives routes for the further interaction of the Russian Federation with unrecognized states in the post-Soviet space in the sphere of foreign economic activity in order to ensure foreign economic security. The author comes to the conclusion that the relations with unrecognized states play an important role in the Russian national interests implementation in the international arena, Russia provides financial support for pragmatic purposes. The most acceptable way of neutralizing threats to Russian economic security is presented. Safe and legal path of sanctions-busting is described. The research concludes that the implementation of foreign economic activity with unrecognized states allows Russia to use those strategies for the settlement of "frozen conflicts", which are the most effective for fuel and energy pressure on the West and assure tranquility on state borders.

Keywords: foreign economic security, foreign economic activity, foreign economic threats, unrecognized states, post-Soviet space, financial support, economic sanctions, raw materials export, strategy, national interests.

На современном этапе социально-экономического развития России, протекающем в условиях глобализации и обострения международной конкуренции, значительное внимание отводится вопросам обеспечения высокого уровня национальной безопасности государства. При этом безопасность внешнеэкономической деятельности представляет собой наиболее важное звено экономической безопасности, служащей гарантом суверенитета страны. Сегодня выдвигаются новые требования к обеспечению национальной безопасности государства для его безальтернативно устойчивого развития на международной арене. 
В связи с этим разработана Стратегия экономической безопасности Российской Федерации на период до 2030 г., утвержденная Указом Президента РФ от 13 мая 2017 г. № 208, в которой отмечается, что итогом ее реализации «должны стать обеспечение экономического суверенитета Российской Федерации и устойчивости национальной экономики к внешним и внутренним вызовам и угрозам, укрепление общественно-политической стабильности, динамичное социальноэкономическое развитие, повышение уровня и улучшение качества жизни населения» [1].

С 2014 г. экономические отношения России со странами Запада стали стремительно ухудшаться, в настоящее время они характеризуются взаимным отчуждением, хотя его степень серьезно варьирует в разных странах Европы. За истекшие пять лет ситуация ухудшилась. Страны Европейского союза (EC) и Соединенные Штаты Америки ввели в действие несколько пакетов экономических санкций, направленных против Российской Федерации. Но санкции - далеко не единственная угроза внешнеэкономической безопасности. К основным угрозам, согласно указанной выше Стратегии, также относятся: «отсутствие российских несырьевых компаний среди глобальных лидеров мировой экономики»; «ограниченность масштабов российского несырьевого экспорта, связанная с его низкой конкурентоспособностью, недостаточно развитой рыночной инфраструктурой и слабой вовлеченностью в мировые цепочки создания добавленной стоимости»; «усиление структурных дисбалансов в мировой экономике и финансовой системе, рост частной и суверенной задолженности, увеличение разрыва между стоимостной оценкой реальных активов и производных ценных бумаг»; «изменение структуры мирового спроса на энергоресурсы и структуры их потребления, развитие энергосберегающих технологий и снижение материалоемкости, развитие зеленых технологий» и многие другие [2].

В статье основное внимание уделяется идентификации реальных угроз, связанных с экономическими отношениями Российской Федерации с непризнанными государствами, образовавшимися на постсоветском пространстве, и выявлению выгод, которые она получает, вкладывая средства в экономическое развитие этих республик.

Российская Федерация ведет внешнеэкономическую деятельность (ВЭД) с рядом самопровозглашенных образований, таких как Абхазия, Южная Осетия, Приднестровье, Донецкая и Луганская народные республики. Традиционно Россию и образовавшиеся государства связывали дружеские отношения вследствие территориальной близости и сходного национального самосознания.

По словам А. Михайлова и Д. Ермакова, Россия несет весьма значительные расходы, связанные с реализацией отдельных приоритетных стратегических направлений ее внешнеэкономической политики. Причинами выступают списание больших долгов других государств, значительное снижение доходов бюджета в связи с отменой таможенных пошлин при поставках энергоресурсов в рамках Евразийского экономического союза (ЕАЭС). Но одно из самых затратных направлений российской внешнеэкономической политики - это финансирование пяти не признанных международным сообществом самопровозглашенных государств [3]. По данным американской частной разведывательно-аналитической компании Stratfor, финансовый вклад РФ в экономику пяти самопровозглашенных республик составляет до 5 млрд долл. США в год (330 млрд р.) [4]. Для сравнения, на здравоохранение в российском бюджете в 2019 г. выделено 653,2 млрд р. [5].

Анализируя ВЭД России, можно охарактеризовать ситуацию следующим образом.

Финансовая помощь, оказываемая Россией Республике Абхазия, в том числе в рамках мероприятий Инвестиционной программы содействия социально-экономическому развитию Республики Абхазия на 2017-2019 гг. [6], в 2019 г. составила 4,409 млрд р., в 2018 г. - 4,291 и в 2017 г. - 4,717 млрд р. [7]. Наибольший вклад в ВВП Абхазии вносят отрасли торговли и строительства, преимущественно за счет инвестиционных средств России. Объем каждой из них больше, чем у промышленности и сельского хозяйства, вместе взятых.

Доля финансового вклада России в бюджет Южной Осетии в 2019 г. составила почти 9 млрд р., или около 82 \% от общей суммы бюджета республики на этот год. В 2018 г. бюджет Республики Южная Осетия на 92,2 \% состоял из федерального финансирования [8]. Основная экономическая отрасль республики - натуральное хозяйство, продукция поставляется главным образом в Россию.

С 2008 г. (после признания Москвой независимости Цхинвала и Сухума) республики Южная Осетия и Абхазия практически введены в финансовую систему России. Наиболее широко используемое платежное средство в указанных регионах - российский рубль.

С 1990-х гг. по настоящее время продолжается внешнеэкономическое сотрудничество России с Приднестровской Молдавской Республикой (ПМР). Основа экономики республики - внешняя торговля: импорт и экспорт топливно-энергетической продукции из РФ, экспорт изделий из металлов, продуктов легкой и пищевой промышленности в Молдавию и Румынию. Финансовая поддержка России заключается в поставке природного газа по льготным тарифам. Кроме того, помощь России ПМР отражается в выплатах пенсий гражданам, имеющим российские паспорта [9]. 
Объявившие независимость Донецкая и Луганская народные республики (ДНР и ЛНР) до начала гражданской войны на Украине в 2014 г. имели многоотраслевую и развитую промышленность. Во время боевых действий и экономической блокады со стороны Украины производственная деятельность на территории ДНР и ЛНР практически остановилась, отчасти была разрушена. Сейчас основной доход республик - налог на добычу и реализацию угля, наибольшую часть импорта составляют товары из России [10]. В 2016 г. агентство финансовой информации Bloomberg сообщало, что РФ оказывает финансовую поддержку ДНР в размере более чем 2 млрд р. ежемесячно на выплаты пенсий [11]. В ДНР и ЛНР до 2015 г. основной денежной единицей была украинская гривна, в настоящее время территории республик фактически являют собой рублевую зону в связи с тем, что наиболее существенные поступления в бюджет - около $90 \%$ - и, соответственно, расходы производятся в рублях [12].

ВЭД Российской Федерации в отношении непризнанных государств является одной из причин введенных санкций и, как следствие, снижения объемов внешнеторгового оборота, ухудшения внутренней и внешней конъюнктуры рынка, что препятствуют сотрудничеству и выходу российских компаний на внешние рынки, падения цен на экспортное сырье, спада промышленного производства, замедления темпов роста экономики и уровня инвестиционной активности, утраты фринансового контроля над отраслями и секторами экономики, а также иных негативных экономических и политических явлений [13].

Примером безопасного и законного способа обхода санкций выступает механизм проведения финнансовых транзакций между РФ, ДНР и ЛНР посредством поддержания каналов оплаты в Южной Осетии. Из-за неопределенного международного статуса ДНР и ЛНР банковские системы этих республик являются замкнутыми и не интегрированы в международную финансовую систему, вследствие чего нет возможности сотрудничать с банками РФ напрямую.

Представителями бизнеса была выработана оптимальная схема сотрудничества, связанная с экспортом товаров из РФ, где работа осуществляется от имени юридического лица, зарегистрированного в Южной Осетии. Республика Южная Осетия признала международно-правовой статус ДНР и ЛНР и согласилась стать юрисдикцией для регистрации предприятий, функционирующих в этих республиках. Первоначально денежные средства перечисляют на счета южноосетинских компаний, а они, в свою очередь, осуществляют расчеты с российскими поставщиками. Такая схема дает возможность реализовывать платежи через так называемую южноосетинскую «прокладку». Несмотря на большой документооборот, существует реальная возможность ведения бизнеса на территории непризнанных республик, приобретения товара у нескольких российских поставщиков для нужд ДНР и ЛНР, которые стали фактически «заложниками» внешнеполитической ситуации.

Неоднократно оказываемая экономическая поддержка непризнанным республикам снижает экономическую безопасность Российской Федерации, делает ее уязвимой перед внешними вызовами, существенно ослабляет позиции государства на мировой арене. ЕС считает, что подобные действия России вызывают напряженность и наносят вред реализации усилий по установлению мира [14, с. 150].

Несмотря на перечисленные угрозы экономической безопасности, стоит отметить, что на данный момент непризнанные республики играют важную роль в реализации национальных интересов России на международной арене. Финансовая поддержка непризнанных территорий осуществляется не только вследствие дружественных намерений и сходного национального самосознания, но и в достаточно в прагматичных целях, определенных национальными интересами государства.

Рассмотрим альтернативные варианты дальнейшего взаимодействия в сфере ВЭД России с непризнанными государствами в целях обеспечения внешнеэкономической безопасности.

Первый вариант заключается в одностороннем признании, а возможно, и присоединении непризнанных территорий. Оценить его влияние довольно сложно, скорее всего, данная стратегия будет одобрена со стороны населения и сопровождаться укреплением рейтинга властей России, но не получит поддержки на международном уровне, и даже наоборот: реализация такого сценария разрушит территориальную целостность сразу нескольких государств, что будет означать полный отход от ранее принятых Хельсинкских соглашений.

Трудно прогнозировать развитие событий в рамках реализации данного варианта, так как каждая деталь может дать непредсказуемый эффект. Нельзя сбрасывать со счетов военный аспект, который может повлечь за собой военную агрессию. Кроме того, присоединение к Российской Федерации непризнанных республик выступит дополнительным политико-экономическим бременем для государства. Также интенсивное экономическое содействие Абхазии, Приднестровью, Южной Осетии вызовет еще большее недовольство в некоторых регионах России, которые не ощущают экономического роста страны. 
Полное дипломатическое признание или присоединение «независимых» территорий наиболее рискованная стратегия, ее реализация приведет к большому экономическому ущербу, возможной дальнейшей дипломатической изоляции и введению дополнительных антироссийских торгово-экономических санкций, что, вероятно, тяжелее для бюджета страны, чем увеличение территории.

Второй вариант - это прекращение оказания финансовой поддержки самопровозглашенным республикам с целью урегулирования конфликтов и содействие сохранению территориальной целостности Грузии, Украины и Молдавии. Несмотря на возможное восстановление экономических отношений с западным миром, отмену введенных торгово-экономических санкций, такой вариант весьма неоднозначен, так как надежды на сохранение территориальной целостности незначительны. Тем более при отсутствии содействия России, например, Донецкая и Луганская республики неминуемо прекратят свое существование - на сегодняшний день нет стопроцентных обстоятельств для создания ими самостоятельных государств. Такой вариант малоприятен и для России, так как, финансово поддерживая непризнанные республики, правительство имеет рычаги давления на страны СНГ и преследует в первую очередь свои экономические цели.

Для внешнеэкономической безопасности России республики Донбасса имеют принципиальное значение в части, касающейся постановки правительства Украины в затруднительное положение политического и военного характера, которое сдерживает ее желание интегрироваться в евро-атлантические структуры. Для России это способ оказания давления на Украину и одно из преимуществ в переговорах с Западом.

Две рассмотренные стратегии наиболее радикальны и прямолинейны для нивелирования внешнеэкономических угроз России и не позволят обеспечить экономическую безопасность на должном уровне.

Третий, компромиссный, вариант взаимодействия России с непризнанными республиками - индивидуальный подход в отношении каждого конфликта (фактически сохранение статускво). Данная политика в наибольшей степени отвечает национальным интересам России и в целом является менее рискованной. Вкладываясь в экономики «независимых» государств, мы получаем неоценимые плюсы: относительно невысокую напряженность на границах, возможность реализации стратегических интересов на этих территориях. Так, России выгодно сохранять влияние на номинальных территориях Молдавии, Украины и Грузии и не допускать их вступления в Североатлантический альянс. Также важно понимать, что давление в нефтегазовой сфере, оказываемое Российской Федерацией на страны Запада, имеет свой предел, так как Россия зависима от закупок западных товаров не менее, чем страны Запада от российских поставок. С нашей точки зрения, при осуществлении ВЭД с непризнанными республиками России выгоден сугубо индивидуальный подход к каждой из них, такая стратегия обеспечит наиболее полную реализацию национальных интересов РФ. На современном этапе экономический вклад в непризнанные государства не менее необходим, чем, например, вложения в здравоохранение и образование.

Подводя итог, отметим, что такая экономическая поддержка в первую очередь служит российским геополитическим интересам, а также обеспечивает военно-стратегическое равновесие на границе. Именно в этом, на наш взгляд, главное преимущество финансовой поддержки непризнанных государств для России.

\section{Ссылки:}

1. О Стратегии экономической безопасности Российской Федерации на период до 2030 г. [Электронный ресурс] : указ Президента РФ от 13 мая 2017 г. № 208 : по сост. на 2 июня 2017 г. Доступ из справ.-правовой системы «КонсультантПлюс».

2. Там же.

3. Михайлов А., Ермаков Д. «Черные дыры» внешней политики [Электронный ресурс] // Профиль : еженедельный журнал. 2017. 3 марта. URL: https://profile.ru/politics/chernye-dyry-vneshnej-politiki-7270/ (дата обращения: 05.02.2020).

4. Goujon E. The Logic and Risks Behind Russia's Statelet Sponsorship [Электронный ресурс] // Stratfor. 2015. Sept. 15. URL: https://worldview.stratfor.com/article/logic-and-risks-behind-russias-statelet-sponsorship (дата обращения: 05.02.2020).

5. Основные направления бюджетной, налоговой и таможенно-тарифной политики на 2019 г. и на плановый период 2020 и 2021 гг. [Электронный ресурс] // Минфин России : офиц. сайт. URL: https://www.minfin.ru/ru/perfomance/budget/policy/?id_57=124752-osnovnye_napravleniya_byudzhetnoi_nalogovoi_i_tamozhenno-tarifnoi_politiki na 2019 god i na planovyi period 2020 i 2021 godov (дата обращения: 05.02.2020).

6. Инвестиционная программа содействия социально-экономическому развитию Республики Абхазия на 2017-2019 гг. [Электронный ресурс] // Министерство экономики Республики Абхазия. URL: http://mineconom-ra.org/upload/iblock/1d5/1d5956b0e971c3446617e351e1aa1b70.pdf (дата обращения: 05.02.2020).

7. Южная Осетия и Абхазия приняли бюджеты на 2019 г. на 80 \% - это деньги россиян [Электронный ресурс] // Красная линия. 2019. 13 февр. URL: https://www.rline.tv/news/2019-02-13-yuzhnaya-osetiya-i-abkhaziya-prinyali-byudzhety-na2019-god-na-80-eto-dengi-rossiyan/ (дата обращения: 05.02.2020).

8. Там же.

9. Михайлов А., Ермаков Д. Указ. соч.

10. Там же. 
11. Johnson S. Prospects for Russia's Sanctions-Bruised Economy Are Dim [Электронный ресурс] // Bloomberg. 2018. November 16. URL: https://www.bloomberg.com/news/articles/2018-11-16/prospects-for-russia-s-sanctions-bruised-economy-are-dim-chart (дата обращения: 29.06.2019).

12. Михайлов А., Ермаков Д. Указ. соч.

13. Galbert S. de. A Year of Sanctions Against Russia - Now What? A European Assessment of the Outcome and Future of Russia Sanctions [Электронный ресурс] / Center for Strategic and International Studies. 2015. October. URL: https://csis-prod.s3.amazonaws.com/s3fs-public/legacy_files/files/publication/150929_deGalbert_SanctionsRussia_Web.pdf (дата обращения: 29.06.2019).

14. Экономическая безопасность : учебник для вузов / Л.П. Гончаренко [и др.]. 2-е изд., перераб. и доп. М., 2019. 340 с.

Редактор, переводчик: Тальчук Калерия Сергеевна 